\title{
Keterampilan Kepala Sekolah Sebagai Manajer dalam Perspektif Kepemimpinan Alkitabiah
}

\author{
I Putu Ayub Darmawan*1, Ruat Diana*2 \\ Sekolah Tinggi Teologi Simpson \\ Email: *1putuayub.simpson@gmail.com, *2rdianadarmawan@gmail.com
}

\begin{abstract}
Skills are part of the competencies that must continue to be built by leaders, including principals. To be a good leader, values are needed in order to be able to hold onto. Christian leadership values based on the Bible need to be presented to enrich the scientific treasures of Christian education. The author conducted a library research to discuss the topic of principals' skills in the perspective of Christian leadership. In carrying out their duties as leaders, principals need to have conceptual skills as seen in the example of leaders in the Bible. Then the principal must also have human skills because based on the value of Christianity, a Christian leader does not carry out his leadership with an iron fist but rather pay attention to human values. Managerial skills are also an important component in the principal's function as a manager. These skills are basic skills that must also be possessed starting from planning, organizing, moving, and controlling.
\end{abstract}

Keywords: Skill, Function, Principal, Manager, Christian Leadership

\begin{abstract}
Abstrak: Keterampilan merupakan bagian dari kompetensi yang terus harus dibangun oleh pemimpin, termasuk kepala sekolah. Untuk menjadi pemimpin yang baik diperlukan nilai-nilai yang dianut agar dapat menjadi pegangan. Nilai-nilai kepemimpinan Kristen yang berlandaskan Alkitab perlu disajikan untuk memperkaya khazanah keilmuan pendidikan Kristen. Penulis melakukan penelitian pustaka untuk membahas topik keterampilan kepala sekolah dalam perspektif kepemimpinan Kristen. Dalam menjalankan tugas sebagai pemimpin, kepala sekolah perlu memiliki keterampilan konseptual sebagaimana tampak dalam contoh pemimpin dalam Alkitab. Kemudian kepala sekolah juga harus memiliki keterampilan manusiawi karena berdasarkan nilai kekristenan, seorang pemimpin Kristen tidak menjalankan kepemimpinannya dengan tangan besi melainkan memperhatikan nilai kemanusiaan. Keterampilan manajerial juga merupakan komponen penting dalam fungsi kepala sekolah sebagai manajer. Keterampilan ini adalah keterampilan dasar yang juga harus dimiliki mulai dari perencanaan, pengorganisasian, pengerakan, dan pengawasan.
\end{abstract}

Kata kunci: Keterampilan, Fungsi, Kepala Sekolah, Manajer, Kepemimpinan Kristen

\begin{tabular}{llll}
\hline Article History : & Received: 19-05-2020 & Revised: 02-06-2020 & Accepted: 02-06-2020 \\
\hline
\end{tabular}

\section{Pendahuluan}

Kepemimpinan Kristen merupakan sebuah konsep kepemimpinan berdasarkan nilai-nilai kekristenan dan Alkitab. Prinsip kepemimpinan Kristen telah mempengaruhi berbagai bidang pekerjaan tidak hanya dalam konteks gereja. Memang menurut Objantoro, konsep dalam kepemimpinan Kristen terimplementasi dalam konteks 
dimana seorang pemimpin Kristen berada. ${ }^{1}$ Kemudian Singgih dan Setiawan mengungkapkan bahwa kepemimpinan Kristen berkaitan dengan pelaksanaan sebuah kepemimpinan dengan nilai-nilai kristiani yang diajarkan oleh Alkitab. ${ }^{2}$ Zaluchu mengungkapkan bahwa kepemimpinan Kristen bukan merupakan sebuah usaha untuk memperoleh kekuasaan melainkan sebuah seni untuk mempengaruhi orang lain. ${ }^{3}$ Sementara Gaol dan Nababan mengungkapkan bahwa kepemimpinan Kristen merupakan proses terencana untuk memudahkan pekerjaan guna mencapai tujuan organisasi. ${ }^{4}$ Bagi Engstrom dan Dayton, kepemimpinan Kristen berbeda dengan kepemimpinan pada umumnya karena tindakan-tindakannya dijalankan berdasarkan nilai-nilai kristiani. ${ }^{5}$ Dengan demikian kepemimpinan Kristen merupakan sebuah proses untuk mencapai tujuan yang dijalankan dengan prinsip-prinsip kekristenan yang berlandaskan Alkitab. Pelaksanaan kegiatan kepemimpinan selalu berkaitan dengan organisasi seperti gereja, perusahaan, lembaga sosial, termasuk juga lembaga pendidikan.

Dalam konteks pendidikan, Kepala Sekolah adalah pemimpin yang bertanggungjawab untuk mengelola sistem dan organisasi sekolah. Dalam melaksanakan hal ini diperlukan sebuah kemampuan untuk menjalankan tugasnya dengan baik sehingga mencapai tujuan organisasi. Proses ini juga berkaitan dengan manajemen yang baik agar organisasi berjalan dengan baik. Manajemen merupakan bagian penting dalam penyelenggaraan sebuah sekolah. Mulyono mengungkapkan bahwa manajemen merupakan sebuah proses yang khas, yang terdiri dari tindakantindakan: perencanaan, penggorganisasian, penggiatan dan pengawasan, yang dilakukan untuk menentukan serta mencapai sasaran-sasaran yang telah ditetapkan melalui pemanfaatan sumber daya manusia dan sumber-sumber lain. ${ }^{6}$ Manajemen merupakan sebuah aktivitas yang berlangsung terus menerus mulai dari perencanaan, pengorganisasian, pengarahan, dan pengawasan serta melibatkan seorang yang bertugas sebagai manajer yang menjalankan aktivitas tersebut. Di sekolah, pekerjaan manajer dan supervisor dirangkap oleh kepala sekolah sebagai administrator. ${ }^{7}$ Dengan

${ }^{1}$ E. Objantoro, "The Contextual Church Leadership," in Melaksanakan Amanat Agung Di Abad, ed. I Putu Ayub Darmawan, vol. 21 (Ungaran: Sekolah Tinggi Teologi Simpson, 2017).

2 Jason Singgih and Roy Setiawan, "Implementasi Christian Leadership Di CV Supratex," Agora 2, no. 1 (2014): 131-140.

3 Sonny Eli Zaluchu, "Respons Tests of Leadership Menurut Teori Frank Damazio Pada Mahasiswa Pascasarjana Jurusan Kepemimpinan Kristen STT Harvest Semarang," Jurnal Jaffray 16, no. 2 (2018): 145160.

4 Nasib Tua Lumban Gaol and Andrianus Nababan, "Kepemimpinan Guru Pendidikan Agama Kristen," Kelola: Jurnal Manajemen Pendidikan 6, no. 1 (2019): 89-96.

5 Ted W. Engstrom and Eedward R. Dayton, Seni Manajemen Bagi Pemimpin Kristen (Bandung: Kalam Hidup, 2007), 16.

6 M. Mulyono, Manajemen Administrasi \& Organisasi Pendidikan, ed. Aziz Safa (Yogyakarta: ArRuzz Media, 2008), 16.

${ }^{7}$ Made Pidarta, Manajemen Pendidikan Indonesia (Jakarta: Rieneka Cipta, 2011), 17. 
memahami hal tersebut kepala sekolah diharapkan akan dapat menjalankan tugasnya sebagai manajer dengan baik dan sekolah akan berjalan dengan baik pula. Kepala sekolah yang tidak memiliki keterampilan akan kesulitan melakukan pekerjaannya. Demikian pula dalam hal fungsinya, bila kepala sekolah tidak memahami apa fungsinya sebagai manajer maka ia akan mengalami kebingungan dalam menjalankan organisasinya. Untuk itu perlu dipahami apa yang merupakan keterampilan manajer dan fungsi pokok dari seorang manajer.

Seorang pemimpin menurut Tambunan perlu memiliki kompetensi pribadi yang berkaitan dengan konsep, skill, maupun pengetahuan yang memadai untuk menjalankan tugasnya. ${ }^{8}$ Dengan demikian dalam konteks kepemimpinan di sekolah, Kepala sekolah sebagai manajer di sekolah perlu memahami apa saja keterampilan yang perlu dimiliki serta apa fungsi pokok dari seorang manajer. Dengan memiliki pengetahuan yang memadai maka diharapkan kepala sekolah dapat menjalankan tugasnya secara maksimal. Tetapi menurut Tambunan, pemimpin juga perlu memiliki karakter yang baik dan menurut Tambunan nilai-nilai kepemimpinan Kristen memberikan jawaban dalam pembentukan karakter pemimpin. ${ }^{9}$ Sementara Gaol dan Siburian mengungkapkan bahwa Kepala Sekolah memiliki tanggungjawab yang berat karena dituntut untuk memiliki kemampuan manajerial dan kepemimpinan agar mampu meningkatkan mutu sekolah, sementara di sisi lain Kepala Sekolah tetap memiliki tanggungjawab utama sebagai guru yang mengajar, membimbing, dan melatih murid. ${ }^{10}$ Oleh sebab itu, kepala sekolah perlu terus ditingkatkan kemampuannya.

Bagi pendidik Kristen yang memiliki tugas tambahan sebagai kepala sekolah, ada nilai-nilai kekristenan yang harus dipahami untuk menjalankan tugasnya. Tomatala menjelaskan bahwa dalam kepemimpinan Kristen, nilai-nilai kekristenan harus dapat dikontekstualisasikan dalam konteks di mana pemimpin itu berada, sementara Tambunan melihat bahwa nilai-nilai kekristen mendorong terciptanya karakter pemimpin yang baik. ${ }^{11}$ Nilai-nilai yang dianut oleh seorang pemimpin tampaknya memiliki peranan penting dalam keberhasilan menjalankan tugas sebagai pemimpin. Walid dalam penelitiannya menemukan bahwa nilai dan keyakinan yang dipegang oleh seorang pemimpin memiliki kontribusi dalam kepemimpinannya. ${ }^{12}$ Werang

8 Fernando Tambunan, "Karakter Kepemimpinan Kristen Sebagai Jawaban Terhadap Krisis Kepemimpinan Masa Kini," ILLUMINATE: Jurnal Teologi dan Pendidikan Kristiani 1, no. 1 (2018): 81-104.

9 Ibid.

10 Nasib Tua Lumban Gaol and Paningkat Siburian, "Peran Kepala Sekolah Dalam Meningkatkan Kinerja Guru," Kelola: Jurnal Manajemen Pendidikan 5, no. 1 (2018): 66-73.

11 Yakob Tomatala, Kepemimpinan Kristen, Mencari Format Kepemimpian Gereja Yang Kontekstual Di Indonesia (Jakarta: YT Leadership Foundation, 2002), 94-97; Tambunan, "Karakter Kepemimpinan Kristen Sebagai Jawaban Terhadap Krisis Kepemimpinan Masa Kini."

12 Muhammad Walid, "Nilai Dan Keyakinan, Kreatifitas, Dan Kepemimpinan Kepala Madrasah Dalam Mengelola Madrasah Ibtidaiyah Negeri Malang 1 Kota Malang," Al Ibtida: Jurnal Pendidikan Guru MI 5, no. 1 (2018): 107-132. 
menjelaskan bahwa nilai dan keyakinan yang dianut akan menciptakan iklim kerja yang baik dan mendorong terjadinya peningkatan mutu dalam sebuah sekolah. ${ }^{13}$

Dari paparan di atas, menurut penulis perlu ada kajian yang berkaitan dengan keterampilan kepala sekolah sebagai manajer dalam perspektif kepemimpinan alkitabiah. Oleh sebab itu, rumusan masalah penelitian ini adalah apa keterampilan kepala sekolah sebagai manajer dalam perspektif kepemimpinan alkitabiah? Tujuan penelitian ini adalah untuk memaparkan tentang keterampilan kepala sekolah sebagai manajer dalam perspektif kepemimpinan alkitabiah.

\section{Metode}

Penulis menggunakan penelitian kualitatif dengan pendekatan studi pustaka. Penelitian ini umumnya digunakan dalam penelitian keagamaan khususnya untuk memahami konsep dalam beberapa teks Alkitab maupun sebuah gagasan. ${ }^{14}$ Beberapa sumber pustaka yang berkaitan dengan manajamen pendidikan dan kepemimpinan Kristen di analisis kemudian disajikan secara deskriptif. Sumber-sumber pustaka dari jurnal dan buku terlebih dahulu diseleksi dengan mencermati kedekatan konsep dan makna. Dalam mengumpulkan sumber-sumber rujukan, penulis memanfaatkan google scholar, portal garuda, google book untuk menemukan beberapa sumber secara daring. Selain itu, penulis juga memanfaatkan sumber-sumber cetak lainnya.

\section{Hasil dan Pembahasan}

\section{Keterampilan Konsep}

Dalam kepemimpinan Kristen, tampak jika Yusuf adalah pemimpin yang memiliki keterampilan konseptual. Menghadapi bencana yang akan terjadi, Yusuf tampil menjadi pemimpin di Mesir dengan keterampilan konseptual yang luar biasa. Kejadian 41-43 menunjukkan sebuah peristiwa yang menggambarkan bahwa Yusuf adalah manajer bagi Mesir dengan keterampilan konseptual yang luar biasa. ${ }^{15}$ Ia mampu merancang sebuah rencana menghadapi kesulitan yang akan terjadi. Selain kisah Yusuf, Musa juga adalah pemimpin yang memiliki keterampilan konseptual yang jelas. Memang hal ini tampaknya dia peroleh dari mertuanya, Yitro. Dalam memimpin bangsa Israel keluar dari Mesir, Musa menghadapi berbagai tantangan dari orang-orang Israel. Menghadapi

13 Basilius Redan Werang, "Pengaruh Keterampilan Managerial Kepala Sekolah Dan Iklim Sekolah Terhadap Komitmen Kerja Guru Sekolah Dasar Kristen Di Kabupaten Boven Digoel," Al Ibtida: Jurnal Pendidikan Guru MI 5, no. 2 (2018): 163.

14 Sonny Eli Zaluchu, "Strategi Penelitian Kualitatif dan Kuantitatif Di Dalam Penelitian Agama," Evangelikal: Jurnal Teologi Injili dan Pembinaan Warga Jemaat 4, no. 1 (2020): 28-38; Hary Purwanto, "Manfaat Penelitian Untuk Perkembangan Gereja," in Prosiding Seminar Nasional Pendidikan Agama Kristen STT Simpson Tahun 2016 Tema: Strategi Pembinaan Jemaat Untuk Meningkatkan Kehidupan Jemaat (Presented at the Seminar Nasional Pendidikan Agama Kristen \& call for papers, Ungaran: Sekolah Tinggi Teologi Simpson, 2016).

${ }^{15}$ Alkitab, TB (Jakarta: Lembaga Alkitab Indonesia, 2011), bk. Kejadian 41-43. 
berbagai persoalan yang terjadi, Musa sebagai pemimpin harus membantu bangsanya menyelesaikan masalah yang terjadi di suku-suku Israel. Dalam menghadapi ini, dengan saran Yitro maka dipilihlah pemimpin seribu orang, pemimpin seratus orang, pemimpin lima puluh orang dan pemimpin sepuluh orang. ${ }^{16}$ Selain mengatur bangsa Israel dalam hal masalah di antara orang Israel, tetapi Musa juga harus mengatur hal-hal kebaktian dan berbagai peraturan lainnya. ${ }^{17}$ Keterampilan konseptual yang Musa miliki bukanlah bawaan lahiriah melainkan sebuah proses dari didikan ketika dia tinggal di istana Firaun, tinggal di rumah Yitro, dan didikan yang Tuhan berikan. Ndapamuri dan Objantoro melihat bahwa pola Musa memimpin bangsa Israel sebagai pola kepemimpinan multi staff yang memungkinkan terjadinya efektivitas organisasi. ${ }^{18}$ Dalam menjalankan model kepemimpinan tersebut, Musa tentunya belajar keterampilan konseptual. Keterampilan tersebut dibutuhkan untuk menjalankan kepemimpinan dengan baik sebab dalam menjalankan tugas sebagai manajer diperlukan konsep, ide, gagasan yang kemudian diimplementasikan.

Dengan landasan tersebut, dapat diimplementasikan dalam kepemimpinan kepala sekolah. Manajer tingkat atas harus memiliki keterampilan untuk membuat konsep, ide, dan gagasan demi kemajuan organisasi. Gagasan atau ide serta konsep tersebut kemudian haruslah dijabarkan menjadi sesuatu rencana kegiatan untuk mewujudkan gagasan atau konsepnya itu. Proses penjabaran ide menjadi sesuatu rencana kerja yang kongkret itu biasanya disebut sebagai proses perencanaan atau planning. Oleh karena itu, keterampilan konsepsional juga merupakan keterampilan untuk membuat rencana kerja. Lebih sederhanya Pidarta dan Mulyono mengungkapkan keterampilan konseptual, merupakan keterampilan untuk memahami dan mengoperasikan organisasi. ${ }^{19}$

Dalam keterampilan konseptual kepala sekolah diharapkan dapat melakukan beberapa kegiatan seperti 1) Melakukan refleksi dengan senantiasa belajar dari pekerjaan sehari-hari, terutama dari cara kerja para guru dan pegawai sekolah lainnya. Releksi dibutuhkan untuk mengetahui hal-hal yang perlu diperbaiki dan ditingkatkan. Refleksi merupakan bagian dari upaya meningkatkan mutu sekolah sebab melalui refleksi akan dirumuskan tindakan perbaikan dengan mencermati kekurangan; ${ }^{20} 2$ ) Melakukan observasi kegiatan manajemen secara terencana. Observasi memberikan informasi yang dibutuhkan untuk merancang kegiatan dan program organisasi; 3) Membaca berbagai hal yang berkaitan dengan kegiatan-kegiatan yang sedang

\footnotetext{
16 Ibid., bk. Keluaran 18.

17 Ibid., bk. Kejadian 20:22-26; 21:12-36; 22-28.

18 Yohanes Ndapamuri and Enggar Objantoro, "Kepemimpinan Multi Staf Dalam Gereja Lokal," Integritas: Jurnal Teologi 1, no. 2 (2019): 123-131.

19 Pidarta, Manajemen Pendidikan Indonesia; Mulyono, Manajemen Administrasi \& Organisasi Pendidikan, 151.

20 Egidius Virgo and Slameto Slameto, “Evaluasi Program Manajerial Kepala Sekolah," Kelola: Jurnal Manajemen Pendidikan 5, no. 2 (2018): 217-229.
} 
dilaksanakan. Informasi dari berbagai hal yang berkaitan dengan kegiatan dapat menjadi sumber informasi teknis maupun sumber informasi petunjuk menjalankan manajemen, kegiatan, dan lain sebagainya yang terkait; 4) Memanfaatkan hasil-hasil penelitian orang lain. Penelitian-penelitian yang dihasilkan oleh orang lain merupakan informasi berharga yang dapat digunakan untuk memajukan kegiatan informasi. Penelitian yang dilakukan di sekolah lain dapat menjadi rujukan maupun refleksi dalam menjalankan fungsi manajer. Sebagai contoh, dalam memecahkan masalah yang terjadi pada guru, Rukayah membutuhkan penelitian yang dilakukan oleh orang lain yang kemudian melakukan penelitian tindakan sekolah untuk meningkatkan mutu pendidikan di sekolah yang dipimpinnya; ${ }^{21}$ 5) Berkipir untuk masa yang akan datang. Kemampuan ini dibutuhkan untuk menentukan visi atau arah sekolah. Dibutuhkan analisis seperti analisis SWOT untuk mengetahui kekuatan, kelemahan, peluang dan ancaman yang akan dihadapi dimasa mendatang. Analisis SWOT dapat digunakan untuk memperoleh gambaran dalam memajukan sistem organisasi sekolah. Hal ini tampak dalam penelitian Sujoko yang meneliti perbaikan rencana strategis sekolah melalui analisis SWOT; ${ }^{22}$ 6) Merumuskan ide-ide yang dapat diujicobakan. Bagian ini tidak dapat dipisahkan dari beberapa kegiatan sebelumnya. Ide-ide yang akan diujicobakan dapat berasal dari informasi yang diperoleh dari kegiatan lainnya. Penelitian Maamarah dan Supramono menunjukkan bahwa ide dan gagasan yang dikembangkan untuk perbaikan mutu membutuhkan informasi dari hasil refleksi, observasi manajemen yang terencana, memperhatikan petunjuk teknis, memanfaatkan hasil penelitian orang lain, menetapkan visi dan tujuan, baru akhiri dengan merumuskan ide yang ingin diimplementasikan. ${ }^{23}$

\section{Kemampuan Komunikasi Interpersonal}

Keterampilan lain yang diperlukan oleh seorang manajer adalah keterampilan berkomunikasi atau keterampilan berhubungan dengan orang lain, yang disebut juga keterampilan komunikasi interpersonal. Komunikasi interpersonal merupakan sebuah bentuk komunikasi antara pribadi dengan orang lain, baik dua orang maupun lebih. ${ }^{24}$ Dalam penelitian Yulianto, Atmadja, dan Yudana tampak bahwa keterampilan komunikasi interpersonal yang dimiliki kepala sekolah memiliki kontribusi bagi kinerja

${ }^{21}$ Rukayah Rukayah, "Peningkatan Kompetensi Guru Dalam Perencanaan Pembelajaran Tematik Melalui Supervisi Kelompok Pendekatan Kolaboratif," Kelola: Jurnal Manajemen Pendidikan 5, no. 1 (2018): 37-46.

22 Edi Sujoko, "Strategi Peningkatan Mutu Sekolah Berdasarkan Analisis SWOT Di Sekolah Menengah Pertama," Kelola: Jurnal Manajemen Pendidikan 4, no. 1 (2017): 83-96.

23 Siti Maamarah and Supramono Supramono, "Strategi Peningkatan Mutu Dan Citra (Image) Sekolah Dasar Negeri Di Ungaran, Semarang," Kelola: Jurnal Manajemen Pendidikan 3, no. 1 (2016): 115130.

83.

${ }^{24}$ Agus M. Hardjana, Komunikasi Interpersonal Dan Intrapersonal (Yogyakarta: Kanisius, 2003), 
guru. $^{25}$ Komunikasi yang persuasif harus selalu diciptakan oleh manajer terhadap bawahan yang dipimpinnya, dalam hal ini kepala sekolah dengan para guru dan staf yang dipimpinnya. Dengan komunikasi yang persuasif, bersahabat, dan kebapakan akan membuat guru dan staf merasa dihargai dan kemudian mereka akan bersikap terbuka kepada atasan. ${ }^{26}$ Keterampilan berkomunikasi diperlukan, baik pada tingkatan manajemen atas, menengah, maupun bawah.

Nilai ini berkaitan dengan konsep servant leadership dalam kepemimpinan Kristen. Katarina dan Siswanto menjelaskan bahwa dalam model kepemimpinan Yesus, Yesus menjadi pemimpin yang mampu mengayomi, mendorong, dan berkomunikasi dengan efektif. ${ }^{27}$ Pendapat Katarina dan Siswanto sejalan dengan Alkitab yang menampilkan sosok Yesus yang mengayomi, mendorong, dan berkomunikasi yang baik dengan para murid-Nya (Mrk. 10:42-43, 45). Dalam konteks pendidikan, konsep yang dikemukakan oleh Ki Hadjar Dewantara juga lekat dengan keterampilan ini. Ki Hadjar Dewantara dalam semboyannya mengemukakan bahwa ing ngarsa sung tuladha, ing madya mangun karsa, tut wuri handayani terdapat nilai-nilai agar di depan menjadi teladan, di tengah memberi semangat dan di belakang memberi dorongan keakutan. ${ }^{28}$ Nilai-nilai tersebut sejalan dengan apa yang Yesus lakukan. Oleh sebab itu, nilai kepemimpinan Kristen dalam keterampilan manusiawi adalah mampu membangun hubungan yang baik dan mendorong terjadinya peningkatan kinerja guru maupun tata usaha di sekolah.

Di sekolah, keterampilan ini dibutuhkan ketika kepala sekolah melakukan supervisi terhadap guru. Dalam melakukan supervisi, kepala sekolah bertanggungjawab agar terjadi peningkatan pada diri guru baik aspek kepribadian maupun kinerja guru. ${ }^{29}$ Dalam menjalankan tugas ini, butuh kebijaksanaan dan sikap rendah hati. Gaol dan Nababan mengungkapkan bahwa dalam kepemimpinan Kristen, seorang pemimpin yang

\footnotetext{
${ }^{25}$ Agus Budi Yulianto, Nengah Bawa Atmadja, and I Made Yudana, "KONTRIBUSI KOMUNIKASI INTERPERSONAL KEPALA SEKOLAH, BUDAYA ORGANISASI DAN ETOS KERJA TERHADAP MOTIVASI KERJA GURU (Studi Kasus Pada Sekolah - Sekolah Dasar Dibawah Yayasan Menorah Abadi Denpasar)," Jurnal Administrasi Pendidikan Indonesia 5, no. 1 (2014).

26 Desi Putry, I. Putu Darmawan, and Edi Sujoko, "Implementing Total Quality Management in Christian Lesson," in Proceedings of the Third Workshop on Multidisciplinary and Its Applications, WMA-3 2019, 11-14 December 2019, Medan, Indonesia, 2020, accessed March 16, 2020, https://eudl.eu/doi/10.4108/eai.11-12-2019.2290810.

27 K. Katarina and Krido Siswanto, "Keteladanan Kepemimpinan Yesus Dan Implikasinya Bagi Kepemimpinan Gereja Pada Masa Kini," Evangelikal: Jurnal Teologi Injili dan Pembinaan Warga Jemaat 2, no. 2 (2018): 87-98.

28 I. Putu Ayub Darmawan and Edi Sujoko, "Understanding Ki Hadjar Dewantara's Educational Philosophy," International Journal of Humanities and Innovation (IJHI) 2, no. 3 (2019): 65-68; Donald Samuel, Gracia Miranda, and Dwi Iga Luhsasi, "Pengembangan Model Evaluasi Metode Pembelajaran Dalam Perspektif Kepemimpinan Guru," in Prosiding Seminar Nasional Dan Bedah Buku "Implementasi Dan Filosofi Ajaran Ki Hadjar Dewantara Dalam Dunia Pendidikan Masa Kini" Dan "Seminar Hasil-Hasil Penelitian Pendidikan" (Presented at the Seminar Nasional dan Bedah Buku "Implementasi dan Filosofi Ajaran Ki Hadjar Dewantara dalam Dunia Pendidikan Masa Kini," Salatiga: Satya Wacana University Press, 2017).

${ }^{29}$ Daniel Kurniawan, Yari Dwikurnaningsih, and Bambang Suteng Sulasmono, "Evaluasi Program Supervisi Akademik Di PAUD Swasta,” Kelola: Jurnal Manajemen Pendidikan 5, no. 2 (2018): 107-123.
} 
melayani dituntut untuk memimpin dengan sikap hati yang bijaksana dan rendah hati, tetapi tetap tegas dan konsisten. ${ }^{30}$ Mencermati kepemimpinan Yesus, tampak jika Ia menjadi pemimpin yang tegas, konsisten, bijaksana dan rendah hati. Ketika Ia berhadapan dengan murid-murid-Nya yang emosional, Yesus justru menjadi pemimpin yang mengoreksi dan mengarahkan murid-murid-Nya untuk lebih tenang. Sepanjang tiga tahun para murid bersama-sama dengan-Nya tampak jika keterampilan ini jelas dilakukan oleh Yesus.

Nilai ini pada dasarnya berlandaskan pada konsep Kejadian 1:26-31 bahwa Allah menciptakan manusia menurut rupa dan gambar Allah kemudian menjalankan pekerjaan yang TUHAN berikan pada manusia. Manusia dalam konteks ini adalah ciptaan yang memiliki satu status yaitu serupa dan segambar dalam rupa Allah. Dalam hal ini, manusia diciptakan memiliki keserupaan dengan Allah yang mencipta, termasuk juga dalam konteks Allah yang bekerja. Walau kemudian jatuh dalam dosa dan mengakibatkan manusia menjadi rusak. Tetapi pada dasarnya manusia tetap harus diperlakukan sebagai ciptaan yang harus dihargai sebagai sesama manusia. Itu artinya dalam konteks kepemimpinan Kristen, tidak boleh ada tindakan diskriminatif terhadap sesama manusia. Sebab, pasca kejatuhan manusia dalam dosa Allah justru menghampiri manusia dan memanusiakan manusia dengan memberi pakaian yang layak. Dalam peristiwa yang dijelaskan dalam Kejadian 3, manusia menyadari dirinya telanjang dan merasa malu, tetapi Allah justru datang pada manusia dan memanusiakan manusia. Allah mengatur manusia secara manusiawi dan mengarahkan agar menjadi sadar akan kesalahannya dan akhirnya takut akan Dia.

Dengan demikian, bagi kepala sekolah dalam menjalankan tugasnya, apabila ada guru maupun staf yang bermasalah maka sebagai manajer ia memiliki fungsi untuk mendorong terjadinya perbaikan diri. Dalam hal ini, artinya tidak diperkenankan untuk bertindak diskriminatif atau merasa superior melainkan dengan rendah hati bersedia menolong guru dan staf yang menjadi bawahannya.

\section{Keterampilan Manajerial}

Dalam keterampilan ini, seorang kepada sekolah dituntut untuk mampu membuat perencanaan yang baik, melakukan pengorganisasian, menggerakkan orangorang yang dimpimpin, dan melakukan pengawasan.

\section{Perencanaan}

Perencanaan merupakan komponen penting dalam sebuah manajemen. Dalam kepemimpinan Kristen, landasan alkitabiah yang melandasi fungsi ini adalah Amsal 31:10-31. Amsal 31:10-31 menunjukkan tentang keberhasilan pekerjaan yang dimulai

30 Gaol and Nababan, "Kepemimpinan Guru Pendidikan Agama Kristen.” 
dari sebuah perencanaan yang baik. Tomatala mengungkapkan bahwa teks Amsal 31:10-31 menunjukkan jika kemampuan merencanakan dengan baik menjadi kunci

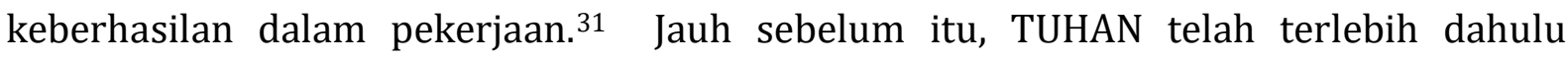
menjadi teladan dalam membuat perencanaan. Dalam peristiwa Kejadian 1:26-28, TUHAN menciptakan manusia dan memulainya dengan kalimat "Baiklah Kita menjadikan manusia menurut gambar dan rupa Kita, supaya mereka berkuasa atas ikanikan di laut dan burung-burung di udara dan atas ternak dan atas seluruh bumi dan atas segala binatang melata yang merayap di bumi."32 Dalam teks tersebut dituliskan bahwa "Baiklah Kita menjadikan manusia menurut gambar dan rupa Kita". Kalimat tersebut menunjukkan bahwa Allah membuat sebuah rencana menciptakan manusia menurut gambar dan rupa-Nya. TUHAN menciptakan manusia agar manusia berkuasa atas segala yang TUHAN ciptakan sebelumnya. Henry menjelaskan bahwa dalam peristiwa ini TUHAN menciptakan manusia sebagai pribadi yang berwewenang dan berperasaan. Dalam rencana-Nya, Ia ingin menciptakan satu makhluk yang berbeda dengan ciptaanciptaan lainnya. ${ }^{33}$ Selain itu, Tomatala juga mencermati dalam Perjanjian Lama ada dua nabi yang membuat perencanaan yang baik untuk mencapai keberhasilan pekerjaannya, yaitu Nehemia dan Yeremia. Tomatala menjelaskan bahwa dalam Nehemia 2:20 tampak bahwa keberhasilan dilandasi oleh pembuatan rencanaan yang baik. ${ }^{34}$ Katarina dan Siswanto menjelaskan bahwa dalam kepemimpinan Kristen, Yesus adalah model pemimpin yang menjadi teladan. ${ }^{35}$ Itu sebabnya, ajaran dan kehidupan Yesus terus dikaji untuk menemukan nilai-nilai penting bagi kepemimpinan. Dalam Lukas 14:28-31 tampak bahwa Yesus juga memberi penekanan bagi manajemen yang baik. Tomatala menjelaskan bahwa dalam teks Lukas 14:28-31, Yesus memberi penegasan bahwa dengan menyusun perencanaan yang baik, sebuah pekerjaan dapat lebih berhasil. ${ }^{36}$

Fungsi perencanaan merupakan proses yang menyangkut upaya yang dilakukan untuk mengantisipasi kecenderungan di masa yang akan datang dan penentuan strategi dan taktik yang tepat untuk mewujudkan target dan tujuan organisasi. Slameto menjelaskan syarat yang harus dipenuhi dalam sebuah perencanaan yang baik adalah: 1) Tujuan harus dirumuskan secara jelas; 2) Bersifat rasional, berdasarkan perhitunganperhitungan yang matang; 3) Disusun secara rinci yang meliputi analisa, jenis-jenis kegiatan, metode kerja dan sebagianya; 4) Mempunyai sifat yang luwes sehingga pada batas tertentu dimungkinkan terjadinya perubahan-perubahan; 5) Ada kesinambungan

31 Yakob Tomatala, Mastering Planning, Pendekatan Pintar Dalam Merencanakan Untuk Memasuki Masa Depan Sukses (Jakarta: YT Leadership Foundation, 2004), 24.

32 Alkitab, bk. Kejadian 1:26.

33 Matthew Henry, Tafsiran Matthew Henry: Kitab Kejadian (Surabaya: Momentum, 2014), 26.

34 Tomatala, Mastering Planning, Pendekatan Pintar Dalam Merencanakan Untuk Memasuki Masa Depan Sukses, 24.

35 Katarina and Siswanto, "Keteladanan Kepemimpinan Yesus Dan Implikasinya Bagi Kepemimpinan Gereja Pada Masa Kini."

36 Tomatala, Mastering Planning, Pendekatan Pintar Dalam Merencanakan Untuk Memasuki Masa Depan Sukses, 24. 
baik ke dalam maupun ke luar. Seimbang ke dalam berarti keseimbangan antara bagianbagian. Seimbang ke luar berarti keseimbangan antara tujuan dan sarana (antara ends dan means); 6) Menggunakan sumber daya secara efektif dan efisien. ${ }^{37}$ Sementara itu kegiatan yang dilakukan oleh seorang manajer dalam perencanaan menurut Dessler adalah menentukan sasaran dan standar-standar; membuat aturan dan prosedur menyusun rencana-rencana dan melakukan peramalan. ${ }^{38}$

Dalam menjalankan fungsi tersebut, dalam konteks kepemimpinan Kristen diperlukan juga nilai-nilai kekristenan yang melandasi perencanaan tersebut. Tomatala menjelaskan bahwa dalam implementasi nilai kekristen dalam kepemipinan, pemimpin juga perlu mencermati nilai dan budaya di mana ia memimpin. ${ }^{39}$ Dari paparan di atas, maka dalam implementasi bagi peran kepala sekolah sebagai manajer di sekolah adalah nilai-nilai yang dianut di sekolah dan nilai kekristenan menjadi perhatian penting.

Dalam menyusun tujuan yang jelas, kepala sekolah hendaknya memperhatikan berbagai aspek baik pada sisi efektivitas dan efisiensi, maupun aspek kemanusiaan. Ketika mengedepankan efektivitas dan efisiensi, aspek kemanusiaan ada kalanya dikorbankan. Misalnya untuk mengefektifkan sebuah sistem dibangunlah sistem informasi agar efektif sekaligus efisien, tetapi akan berdampak pada aspek kemanusiaan. Itu sebabnya bagi pemimpin Kristen, dibutuhkan hikmat daripada Allah untuk membuat sebuah tujuan dalam perencanaan dan bergantung pada sumbersumber Alkitab yang dapat memberi pengetahuan akan nilai-nilai kekristen dalam menyusun tujuan. Mawikere mengungkapkan bahwa penting bagi seorang pemimpin Kristen untuk mencari landasan Alkitab dalam melaksanakan fungsinya sebagai pemimpin. ${ }^{40}$

Karena dalam perencanaan, sebuah rencana harus bersifat rasional, berdasarkan perhitungan-perhitungan yang matang maka kepala sekolah butuh kehati-hatian, ketelitian, dan ketenangan berpikir. Slameto mengungkapkan bahwa dalam tugas ini, kepala sekolah memiliki peranan penting merencanakan anggaran pendapatan dan belanja sekolah. ${ }^{41}$ Perencanaan anggaran tersebut berkaitan dengan kelangsungan penyelenggaraan pendidikan dalam tingkat sekolah. Oleh sebab itu, dalam tahap diperlukan analisa yang mendalam seperti terhadap jenis-jenis kegiatan dan metode kerja. Contoh dalam Perjanjian Lama yang menunjukkan adanya analisis yang mendalam untuk membuat rencana adalah dalam peristiwa perjalanan bangsa Israel

\footnotetext{
37 Slameto, Manajemen Pendidikan (Salatiga: Widya Sari Press, 2009), 27.

38 Dessler Gary, Manajemen Sumber Daya Manusia, Jilid 1, Kesepuluh. (Jakarta: Indeks, 20007), 4. Indonesia, 97.

39 Tomatala, Kepemimpinan Kristen, Mencari Format Kepemimpian Gereja Yang Kontekstual Di

40 Marde Christian Stenly Mawikere, "Efektivitas, Efisiensi Dan Kesehatan Hubungan Organisasi Pelayanan Dalam Kepemimpinan Kristen," Evangelikal: Jurnal Teologi Injili dan Pembinaan Warga Jemaat 2, no. 1 (2018): 50-67.

41 Virgo and Slameto, “Evaluasi Program Manajerial Kepala Sekolah,” 221.
} 
keluar dari Mesir. Dalam Bilangan 13 tampak bahwa untuk mengambil keputusan, Musa memerintahkan dua belas pengintai untuk melakukan survey di tanah Kanaan. Dalam peristiwa tersebut, perencanaan yang baik membutuhkan rasa optimis untuk mencapai keberhasilan pekerjaan. Ronda mengungkapkan ketika ada keraguan dalam menyusun rencana maka diperlukan spiritualitas yang berlandaskan prinsip Alkitab agar dapat menjalankan tugas sebagai pemimpin dengan baik. ${ }^{42}$

\section{Pengorganisasian}

Melihat dari apa yang Yusuf lakukan di Mesir, kemudian yang Musa lakukan dalam memimpin bangsa Isreal keluar dari Mesir, tampak mereka melakukan perorganisasian dalam tugas mereka. Fungsi pengorganisasian adalah proses yang menyangkut bagaimana strategi dan taktik yang telah dirumuskan dalam perencanaan didesain dalam sebuah struktur organisasi yang tepat dan tangguh, sistem dan lingkungan organisasi yang kondusif, dan dapat memastikan bahwa semua pihak dalam organisasi dapat bekerja secara efektif dan efisien guna pencapaian tujuan organisasi organisasi. $^{43}$ Untuk meningkatkan organisasi yang dijalankan maka dalam pengorganisasian dilakukan pengelompokan orang-orang bersadarkan tugas, wewenang dan tanggungjawabnya. ${ }^{44}$ Dalam lingkup sekolah, kepala sekolah melakukan penempatan sumber daya manusia pada posisi yang paling tepat seperti staf tata usaha, guru kelas yang tepat dan sesuai dengan tujuan yang ingin dicapai oleh sekolah.

Dalam Kisah Para Rasul 20:17-38 tampak jika Paulus melakukan tugas manajerial dengan berbicara prinsip-prinsip tentang pelayanan dengan para penatua. Dalam bagian tersebut, Sudibyo mengungkapkan bahwa Paulus menekankan jika setiap hamba Tuhan dipanggil Allah untuk melakukan pekerjaan-Nya, dan melakukan tugas pelayanan dengan kesadaran bahwa Allah memanggil untuk melakukan pekerjaan dengan penuh tanggungjawab. ${ }^{45}$ Setiap penatua yang ditugaskan dalam pelayanan ditugaskan sebagai tanggungjawab pada panggilan Allah dan mengerjakan pelayanan sesuai kapasitasnya.

Dalam konteks kepemimpinan kepala sekolah, dalam mengorganisasikan staf maupun guru harus memperhatikan kapasitas masing-masing. Kemudian memberi

42 Daniel Ronda, "Kepemimpinan Kristen di Era Disrupsi Teknologi," Evangelikal: Jurnal Teologi Injili dan Pembinaan Warga Jemaat 3, no. 1 (January 30, 2019): 1-8.

43 Maha Alkhaffaf, Monira Muflih, and Mahmoud Al-Dalahmeh, "An Integrated Model of Knowledge Management Enablers and Organizational Creativity: The Mediating Role of Knowledge Management Processes in Social Security Corporation In Jordan," Journal of Theoretical and Applied Information Technology 96, no. 3 (2005): 677-700; Peter E. D. Love et al., "Total Quality Management and the Learning Organization: A Dialogue for Change in Construction," Construction Management and Economics 18, no. 3 (2000): 321-331.

44 Slameto, Manajemen Pendidikan, 28.

45 Irwanto Sudibyo, "Pelayanan Kepemimpinan Penggembalaan Menurut Kisah Para Rasul 20:1738," Jurnal Teologi Gracia Deo 2, no. 1 (2019): 46-61. 
penekanan bahwa tugas yang dipercayakan merupakan pekerjaan yang harus dipertanggungjawabkan pada Allah.

\section{Pengerakan}

Dalam Perjanjian Baru, Paulus melakukan penggerakan di kalangan jemaat agar mendukung pekerjaan Tuhan. Dalam Surat 1 Timotius tampak jika Paulus menempatkan Timotius untuk mengatur pelayanan di Efesus. Sementara dalam bagian lain tampak juga Paulus mengatur penatua jemaat agar mengatur pelayanan dengan baik. Paulus ingin agar jemaat berusaha mengerjakan pelayanan di jemaat.

Slameto menyatakan bahwa actuating adalah tindakan untuk mengusahakan agar semua anggota kelompok (organisasi) mau berusaha mencapai sasaran-sasaran yang telah di tetapkan agar sesuai dengan perencanaan manajerial dan usaha-usaha organisasi. ${ }^{46}$ Fungsi penggerakan adalah sebuah proses implementasi program agar dapat dijalankan oleh seluruh pihak dalam organisasi serta proses memotivasi agar semua pihak tersebut dapat menjalankan tanggungjawabnya dengan penuh kesadaran dan produktifitas yang tinggi. ${ }^{47}$

Dalam kepemimpinan Kristen, pemimpin harus menggerakan segala sumber daya yang telah ditempatkan untuk dipimpin dengan penuh kasih dan menjalankan tanggungjawab secara kristiani.

\section{Pengawasan}

Dalam model kepemimpinan Musa, tampak dalam upaya memecahkan masalah yang terjadi di antara bangsa Israel, Musa memungsikan para pemimpin di bawahnya untuk melakukan pengawasan. Setiap orang yang menjadi pemimpin di bawah Musa adalah orang-orang yang dipilih dari setiap suku dan memiliki kualifikasi yang memadai. Pengawasan dilaksanakan bukan sebagai upaya mempersalahkan staf bawahannya melainkan sebagai bentuk menjaga kualitas dan tanggung jawab. Engstrom dan Dayton memandang bahwa ada tanggung jawab besar pada setiap pemimpin untuk menjamin keberlangsungan organisasinya. Oleh sebab itu dibutuhkan pengawasan maupun audit baik audit organisasi, audit program, audit pribadi, maupun audit keuangan. ${ }^{48}$ Dalam menjalankan kegiatan pengawasan, seorang pemimpin dituntut memiliki kasih Kristus sehingga tindakan yang dilakukan dengan semua dinamikanya tetap sejalan dengan

${ }^{46}$ Slameto, Manajemen Pendidikan, 31.

47 Semuel Batlajery, "Penerapan Fungsi-Fungsi Manajemen Pada Aparatur Pemerintahan Kampung Tambat Kabupaten Merauke," Jurnal Ilmu Ekonomi \& Sosial 7, no. 2 (2016): 135-155; Alkhaffaf, Muflih, and Al-Dalahmeh, "An Integrated Model of Knowledge Management Enablers and Organizational Creativity: The Mediating Role of Knowledge Management Processes in Social Security Corporation In Jordan."

\footnotetext{
${ }^{48}$ Engstrom and Dayton, Seni Manajemen Bagi Pemimpin Kristen, 63-68.
} 
prinsip kekristenan (II Kor. 5:13-14; I Kor. 13; 1 Yoh. 4:7-10). ${ }^{49}$ Dengan wawasan nilai kekristenan tersebut yang melandasi kepemimpinan Kristen maka fungsi kepala sekolah sebagai manajer dijalankan dengan penuh kasih. Itu artinya, kepala sekolah tidak menjalankan fungsinya sebagai penguasa melainkan dengan penuh kasih melakukan pengawasan yang mendorong terjadinya peningkatan mutu.

Fungsi pengawasan adalah proses yang dilakukan untuk memastikan seluruh rangkaian kegiatan yang telah direncanakan, diorganisasikan dan diimplementasikan dapat berjalan sesuai dengan target yang diharapkan sekalipun berbagai perubahan terjadi dalam lingkungan dunia bisnis yang dihadapi. Pidarta menjelaskan bahwa kegiatan pengawasan dilakukan dengan maksud agar: 1) perilaku personalia organisasi mengarah ke tujuan organisasi, bukan semata-mata ke tujuan individual mereka masing-masing; dan 2) agar tidak terjadi penyimpangan yang berarti antara rencana dengan pelaksanaan. Dijelaskan oleh Pidarta bahwa penyimpangan antara rencana dengan pelaksanaan sangat mungkin terjadi kalau tidak diadakan kontrol. ${ }^{50}$

\section{Kesimpulan}

Kepemimpinan Kristen merupakan sebuah proses menjalankan sebuah sistem untuk mencapai tujuan organisasi berlandaskan nilai-nilai kekristenan. Alkitab memberikan landasan nilai kekristenan yang kemudian menjadi landasan bagi kepemimpinan Kristen. Kepemimpinan tidak hanya terkait dengan perusahaan, organisasi besar, kepala daerah, dan lain sebagainya. Kepemimpinan juga terkait dengan lembaga pendidikan dimana ada kepala sekolah yang menjalankan tugas sebagai pemimpin. Kepala sekolah sebagai manajer di sekolah yang dipimpinnya perlu didukung dengan keterampilan konseptual, manusiawi, dan teknik manajerial sehingga kinerjanya sebagai pemimpin akan lebih baik. Keterampilan tersebut juga dilandaskan pada nilainilai kekristenan yang melandasi nilai kepemimpinan Kristen. Prinsip dan contoh dari Alkitab menjadi landasan prinsip menjalan fungsi kepala sekolah sebagai manajer. Fungsi pokok sebagai manajer harus dipahami dengan dengan baik sehingga dapat melakukan perencanaan dengan matang, pengorganisasian dengan tepat, penggerakan dan pengawasan yang baik.

\section{Referensi}

Alkhaffaf, Maha, Monira Muflih, and Mahmoud Al-Dalahmeh. "An Integrated Model of Knowledge Management Enablers and Organizational Creativity: The Mediating Role of Knowledge Management Processes in Social Security Corporation In Jordan." Journal of Theoretical and Applied Information Technology 96, no. 3 (2005): 677-700.

49 Tomatala, Kepemimpinan Kristen, Mencari Format Kepemimpian Gereja Yang Kontekstual Di Indonesia, 43-45.

50 Pidarta, Manajemen Pendidikan Indonesia, 162. 
Batlajery, Semuel. "Penerapan Fungsi-Fungsi Manajemen Pada Aparatur Pemerintahan Kampung Tambat Kabupaten Merauke." Jurnal Ilmu Ekonomi \& Sosial 7, no. 2 (2016): $135-155$.

Darmawan, I. Putu Ayub, and Edi Sujoko. "Understanding Ki Hadjar Dewantara's Educational Philosophy." International Journal of Humanities and Innovation (IJHI) 2, no. 3 (2019): 65-68.

Engstrom, Ted W., and Eedward R. Dayton. Seni Manajemen Bagi Pemimpin Kristen. Bandung: Kalam Hidup, 2007.

Gaol, Nasib Tua Lumban, and Andrianus Nababan. "Kepemimpinan Guru Pendidikan Agama Kristen.” Kelola: Jurnal Manajemen Pendidikan 6, no. 1 (2019): 89-96.

Gaol, Nasib Tua Lumban, and Paningkat Siburian. "Peran Kepala Sekolah Dalam Meningkatkan Kinerja Guru." Kelola: Jurnal Manajemen Pendidikan 5, no. 1 (2018): 6673.

Gary, Dessler. Manajemen Sumber Daya Manusia, Jilid 1. Kesepuluh. Jakarta: Indeks, 20007.

Hardjana, Agus M. Komunikasi Interpersonal Dan Intrapersonal. Yogyakarta: Kanisius, 2003.

Henry, Matthew. Tafsiran Matthew Henry: Kitab Kejadian. Surabaya: Momentum, 2014.

Katarina, K., and Krido Siswanto. "Keteladanan Kepemimpinan Yesus Dan Implikasinya Bagi Kepemimpinan Gereja Pada Masa Kini." Evangelikal: Jurnal Teologi Injili dan Pembinaan Warga Jemaat 2, no. 2 (2018): 87-98.

Kurniawan, Daniel, Yari Dwikurnaningsih, and Bambang Suteng Sulasmono. "Evaluasi Program Supervisi Akademik Di PAUD Swasta." Kelola: Jurnal Manajemen Pendidikan 5, no. 2 (2018): 107-123.

Love, Peter E. D., Heng Li, Zahir Irani, and Olusegun Faniran. “Total Quality Management and the Learning Organization: A Dialogue for Change in Construction." Construction Management and Economics 18, no. 3 (2000): 321-331.

Maamarah, Siti, and Supramono Supramono. "Strategi Peningkatan Mutu Dan Citra (Image) Sekolah Dasar Negeri Di Ungaran, Semarang." Kelola: Jurnal Manajemen Pendidikan 3, no. 1 (2016): 115-130.

Mawikere, Marde Christian Stenly. "Efektivitas, Efisiensi Dan Kesehatan Hubungan Organisasi Pelayanan Dalam Kepemimpinan Kristen." Evangelikal: Jurnal Teologi Injili dan Pembinaan Warga Jemaat 2, no. 1 (2018): 50-67.

Mulyono, M. Manajemen Administrasi \& Organisasi Pendidikan. Edited by Aziz Safa. Yogyakarta: Ar-Ruzz Media, 2008.

Ndapamuri, Yohanes, and Enggar Objantoro. "Kepemimpinan Multi Staf Dalam Gereja Lokal." Integritas: Jurnal Teologi 1, no. 2 (2019): 123-131. 
Objantoro, E. "The Contextual Church Leadership." In Melaksanakan Amanat Agung Di Abad, edited by I Putu Ayub Darmawan. Vol. 21. Ungaran: Sekolah Tinggi Teologi Simpson, 2017.

Pidarta, Made. Manajemen Pendidikan Indonesia. Jakarta: Rieneka Cipta, 2011.

Purwanto, Hary. "Manfaat Penelitian Untuk Perkembangan Gereja." In Prosiding Seminar Nasional Pendidikan Agama Kristen STT Simpson Tahun 2016 Tema: Strategi Pembinaan Jemaat Untuk Meningkatkan Kehidupan Jemaat. Ungaran: Sekolah Tinggi Teologi Simpson, 2016.

Putry, Desi, I. Putu Darmawan, and Edi Sujoko. "Implementing Total Quality Management in Christian Lesson." In Proceedings of the Third Workshop on Multidisciplinary and Its Applications, WMA-3 2019, 11-14 December 2019, Medan, Indonesia, 2020. Accessed March 16, 2020. https://eudl.eu/doi/10.4108/eai.11-122019.2290810.

Ronda, Daniel. “Kepemimpinan Kristen di Era Disrupsi Teknologi.” Evangelikal: Jurnal Teologi Injili dan Pembinaan Warga Jemaat 3, no. 1 (January 30, 2019): 1-8.

Rukayah, Rukayah. "Peningkatan Kompetensi Guru Dalam Perencanaan Pembelajaran Tematik Melalui Supervisi Kelompok Pendekatan Kolaboratif." Kelola: Jurnal Manajemen Pendidikan 5, no. 1 (2018): 37-46.

Samuel, Donald, Gracia Miranda, and Dwi Iga Luhsasi. "Pengembangan Model Evaluasi Metode Pembelajaran Dalam Perspektif Kepemimpinan Guru." In Prosiding Seminar Nasional Dan Bedah Buku "Implementasi Dan Filosofi Ajaran Ki Hadjar Dewantara Dalam Dunia Pendidikan Masa Kini" Dan "Seminar Hasil-Hasil Penelitian Pendidikan." Salatiga: Satya Wacana University Press, 2017.

Singgih, Jason, and Roy Setiawan. "Implementasi Christian Leadership Di CV Supratex." Agora 2, no. 1 (2014): 131-140.

Slameto. Manajemen Pendidikan. Salatiga: Widya Sari Press, 2009.

Sudibyo, Irwanto. "Pelayanan Kepemimpinan Penggembalaan Menurut Kisah Para Rasul 20:17-38." Jurnal Teologi Gracia Deo 2, no. 1 (2019): 46-61.

Sujoko, Edi. "Strategi Peningkatan Mutu Sekolah Berdasarkan Analisis SWOT Di Sekolah Menengah Pertama." Kelola: Jurnal Manajemen Pendidikan 4, no. 1 (2017): 83-96.

Tambunan, Fernando. "Karakter Kepemimpinan Kristen Sebagai Jawaban Terhadap Krisis Kepemimpinan Masa Kini." ILLUMINATE: Jurnal Teologi dan Pendidikan Kristiani 1, no. 1 (2018): 81-104.

Tomatala, Yakob. Kepemimpinan Kristen, Mencari Format Kepemimpian Gereja Yang Kontekstual Di Indonesia. Jakarta: YT Leadership Foundation, 2002.

- - - Mastering Planning, Pendekatan Pintar Dalam Merencanakan Untuk Memasuki Masa Depan Sukses. Jakarta: YT Leadership Foundation, 2004. 
Virgo, Egidius, and Slameto Slameto. "Evaluasi Program Manajerial Kepala Sekolah." Kelola: Jurnal Manajemen Pendidikan 5, no. 2 (2018): 217-229.

Walid, Muhammad. "Nilai Dan Keyakinan, Kreatifitas, Dan Kepemimpinan Kepala Madrasah Dalam Mengelola Madrasah Ibtidaiyah Negeri Malang 1 Kota Malang." Al Ibtida: Jurnal Pendidikan Guru MI 5, no. 1 (2018): 107-132.

Werang, Basilius Redan. "Pengaruh Keterampilan Managerial Kepala Sekolah Dan Iklim Sekolah Terhadap Komitmen Kerja Guru Sekolah Dasar Kristen Di Kabupaten Boven Digoel." Al Ibtida: Jurnal Pendidikan Guru MI 5, no. 2 (2018): 159-174.

Yulianto, Agus Budi, Nengah Bawa Atmadja, and I Made Yudana. "Kontribusi Komunikasi Interpersonal Kepala Sekolah, Budaya Organisasi Dan Etos Kerja Terhadap Motivasi Kerja Guru (Studi Kasus Pada Sekolah - Sekolah Dasar Dibawah Yayasan Menorah Abadi Denpasar)." Jurnal Administrasi Pendidikan Indonesia 5, no. 1 (2014).

Zaluchu, Sonny Eli. "Respons Tests of Leadership Menurut Teori Frank Damazio Pada Mahasiswa Pascasarjana Jurusan Kepemimpinan Kristen STT Harvest Semarang." Jurnal Jaffray 16, no. 2 (2018): 145-160.

- - - "Strategi Penelitian Kualitatif dan Kuantitatif Di Dalam Penelitian Agama." Evangelikal: Jurnal Teologi Injili dan Pembinaan Warga Jemaat 4, no. 1 (2020): 28-38.

Alkitab. TB. Jakarta: Lembaga Alkitab Indonesia, 2011. 